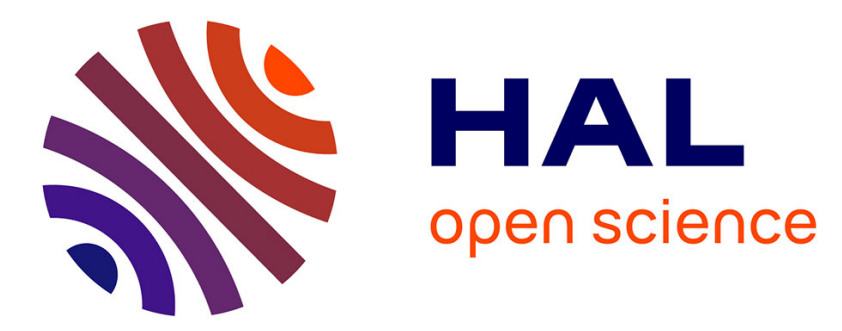

\title{
Biocompatible silica-based magnesium composites
}

Devadas Bhat Panemangalore, Rajashekhara Shabadi, David Tingaud, Matthieu Touzin, G Ji

\section{To cite this version:}

Devadas Bhat Panemangalore, Rajashekhara Shabadi, David Tingaud, Matthieu Touzin, G Ji. Biocompatible silica-based magnesium composites. Journal of Alloys and Compounds, 2019, 772, pp.4957. 10.1016/j.jallcom.2018.09.060 . hal-03323864

\section{HAL Id: hal-03323864 https://hal.science/hal-03323864}

Submitted on 23 Aug 2021

HAL is a multi-disciplinary open access archive for the deposit and dissemination of scientific research documents, whether they are published or not. The documents may come from teaching and research institutions in France or abroad, or from public or private research centers.
L'archive ouverte pluridisciplinaire HAL, est destinée au dépôt et à la diffusion de documents scientifiques de niveau recherche, publiés ou non, émanant des établissements d'enseignement et de recherche français ou étrangers, des laboratoires publics ou privés. 


\section{Biocompatible silica-based magnesium composites}

Devadas Bhat Panemangalore ${ }^{\mathrm{a}}$, Rajashekhara Shabadi ${ }^{\mathrm{a}}$, David Tingaud ${ }^{\mathrm{b}}$, Matthieu Touzin ${ }^{\mathrm{a}}$, Gang $\mathrm{Ji}^{\mathrm{a}}$

a Groupe de Métallurgie Physique \& Génie des Matériaux /UMET, CNRS UMR 8207, Université Lille1, Villeneuve d'Ascq, France.

${ }^{\text {b} U n i v e r s i t e ́ ~ P a r i s ~ 13, ~ S o r b o n n e ~ P a r i s-C i t e ́, ~} 99$ avenue Jean-Baptiste Clément, 93430 Villetaneuse, France

Corresponding author:

Dr. Rajashekhara Shabadi

Unité Matériaux Et Transformations

University of Lille

59650 Lille, France

T : +33 (0) 3203362 24, F : +33 (0) 320436591 ; Email : rajashekhara.shabadi@univ$\underline{\text { lille1.fr }}$ 


\begin{abstract}
:
In this study, an in-situ formed $\mathrm{Mg}_{2} \mathrm{Si}-\mathrm{Mg}$ composite is investigated to understand the formation of $\mathrm{Mg}_{2} \mathrm{Si}$ and its influence in mechanical properties and corrosion behavior. A starting blend of $2.5 \mathrm{wt} . \% \mathrm{SiO}_{2}$ nanoparticles and magnesium powders was used to elaborate in-situ composite through mechanical blending followed by spark plasma sintering technique. High temperature X-ray diffraction measurements and differential scanning calorimetry results confirmed the formation of $\mathrm{Mg}_{2} \mathrm{Si}$ phase. The addition of 2.5 wt.\% $\mathrm{SiO}_{2}$ enhanced hardness while the stiffness values remained the same. The results of potentiodynamic polarization tests revealed an improved corrosion resistance of $\mathrm{Mg}$ reinforced with $\mathrm{SiO}_{2}$ nanoparticles. Thus, this work is an attempt to understand the fabrication (dissociation of silica into $\mathrm{Mg}_{2} \mathrm{Si}$ in presence of $\mathrm{Mg}$ ) and corrosion properties of silica reinforced magnesium composites with those of pure magnesium targeting biomedical applications.
\end{abstract}

Keywords: magnesium; biocompatibility; silica; spark plasma sintering

\title{
1. Introduction
}

High strength and corrosion resistant materials like titanium, Ti-6Al-4V and SS316L are being largely used for fixation of bone and as implant materials in orthopedic applications. However, major shortcomings of these materials are their high elastic moduli which lead to stress-shielding effect [1]. Moreover they are non-degradable [2] and, hence, require postoperative measures, which come at an additional expense and pain that causes a lot of inconvenience to the patients. Therefore, it is important to develop next generation implant materials that resemble the mechanical properties of bones that counter the 'stress shielding effect' and also are bio-degradable.

Over the past few years, research on biodegradable metals like magnesium, its alloys and composites has gained lot of momentum [3] as magnesium has its elastic modulus close to 
that of cortical bone [4] and is an essential mineral for a human metabolism. More importantly, it is biodegradable, i.e., gets absorbed after fixing the bone and its regeneration [5]. However, a major concern is its poor corrosion behavior under conducive environments [6]. To improve their bio-corrosion behavior and to make it bio-compatible with controlled degradability, two metallurgical approaches can be used: 1. alloying and 2. synthesized composites. In the literature, alloying magnesium involve binary [7], ternary [8] or quaternary additions [9] to pure magnesium in order to reduce hydrogen gas formation and maintain the surface and chemical integrity of implant materials. However, the major shortcomings of these alloys are maintaining the purity, homogeneity and composition to prevent excessive degradation. Discussion on the alloys is not considered here as it falls out of the scope of the present work. We limit further discussions only to composites and in particularly, silica-based Mg matrix composites.

Magnesium based composites with reinforcements including several oxides, alumina [10], zirconia [11], titania [12], silica [13] have been studied, either as a reinforcing material or in the form of coatings. Alumina particle reinforcements on magnesium scaffolds were studied by Kang et al [10] for biomedical applications. A 5 wt.\% addition led to a slight increase in corrosion as compared to pure magnesium in $\mathrm{SBF}$ solution and hence a coating of $\mathrm{MgF}_{2}$ was introduced that reduced the corrosion rate drastically. Nano-zirconia coating using electrophoretic deposition on AZ91D magnesium alloy for biomedical applications were done by Amiri et al. [11]. Although AZ91D shows better corrosion resistance, it is not widely accepted as a biocompatible material as a $9 \mathrm{wt} . \%$ aluminum in this alloy could induce risk for Alzheimer's disease [14]. Coatings of titania on magnesium have been studied in detail [12] but a very limited research is available on its usage as a reinforcement material for pure $\mathrm{Mg}$ for biomedical applications. Nano silica was selected in this study as a reinforcement because of its high biocompatibility [15] and in moderate dosages, it shows no signs of toxicity in the 
human body fluids [16]. It is bioactive and biodegradable material that aids in bone repair and regeneration [17]. Hence, in the present study we are concentrating on the influence of silica on the dissociation capacity into $\mathrm{Mg}_{2} \mathrm{Si}$ in the presence of $\mathrm{Mg}$ to become $\mathrm{Mg}_{2} \mathrm{Si}-\mathrm{Mg}$ composites, during in-situ synthesis, and also because there is very little research available on the nano-silica $\mathrm{Mg}$ composites. Mesoporous silica nanoparticles which are hollow and biodegradable are known to enhance antitumor efficiency [18]. Using tetraethyl orthosilicate, Kursawe et al. [19] synthesized biodegradable silica fibers for reinforcement of medical implants using sol-gel processing. Bio-silica, which is the main mineral component of sponge silicatein aids in treatment of human bone diseases and dysfunctions [20]. Also, bio-silica is known to stimulate the formation of hydroxyapatite by mineralizing cells [21]. Silica nanoparticles are also known to be multifunctional as they possess the potential of imaging and gene delivery [22]. There have been several ongoing researches on reinforcing silica with magnesium for the enhancement of mechanical properties. Parande et al. used low volume fraction of 10-20 nm silica nanoparticulates to enhance the hardness, compression and damping response of magnesium [23].

$\mathrm{Lu}$ et al. studied the formation of $\mathrm{Mg}_{2} \mathrm{Si}$ via mechanical alloying of elemental $\mathrm{Mg}$ and $\mathrm{Si}$ powders [24]. Wang et al. synthesized nanocrystalline $\mathrm{Mg}_{2} \mathrm{Si}$ using ball milling of elemental powders and found enhanced fracture toughness compared to pure magnesium [25]. Kondoh et al. also adopted powder metallurgy route in solid-state synthesis of $\mathrm{Mg}_{2} \mathrm{Si}$ intermetallic compounds but using a technique called repeated plastic working with compaction and extrusion using pure elemental powders [26]. Sun et al. studied the synthesis kinetics during the formation of $\mathrm{Mg}-\mathrm{Mg}_{2} \mathrm{Si}$ composite and concluded that at temperatures below $580^{\circ} \mathrm{C}$, the elemental powders did not react completely to form $\mathrm{Mg}_{2} \mathrm{Si}$ [27]. In-house scraps of the wrought optical silica glass fiber were milled with AZ31 by Kondoh et al. to fabricate composites by consolidation, heating and hot-extrusion [28]. However, they couldn't be used 
for bio-medical applications as they did contain lot of impurities as they were manufactured from scrap materials. Using hot-pressing technique, Myalska et al. synthesized in-situ $\mathrm{Mg}$ metal matrix composites based on hydrophilic fumed silica nanoparticles of $5 \mathrm{~nm}$ size and they comprised of $\mathrm{Mg}_{2} \mathrm{Si}$ and $\mathrm{MgO}$ dispersoids [29]. Gupta et al. [30] studied the electrochemical behavior of $\mathrm{Mg}_{2} \mathrm{Si}$ particles in AS31 magnesium alloy and AA6360-T6 and AA7075-T651 aluminum alloys in both acidic and alkaline medium. The intermetallic $\mathrm{Mg}_{2} \mathrm{Si}$ was found to be active at low $\mathrm{pH}$ and passive at high $\mathrm{pH}$ conditions. Also the $\mathrm{Mg}_{2} \mathrm{Si}$ in $\mathrm{Al}$ matrix was found to serve as a local anode, whereas in $\mathrm{Mg}$ matrix, the $\mathrm{Mg}_{2} \mathrm{Si}$ remained intact while the surrounding matrix gets corroded. Ben-Hamu et al. found improved corrosion behavior of wrought $\mathrm{Mg}-\mathrm{Zn}-\mathrm{Mn}$ alloy with the presence of polygonal shape $\mathrm{Mg}_{2} \mathrm{Si}$ intermetallics [31,32]. Also, as reported by Kondoh et al. the corrosion resistance of $\mathrm{Mg}_{2} \mathrm{Si}$ is better than that of stainless steels [28]. This conclusion was arrived based on salt spray tests according to JIS Z 2731 standard conducted on intermetallic bulk $\mathrm{Mg}_{2} \mathrm{Si}$ and conventional 304 stainless steel. At room temperature, corrosion phenomenon was not observed after $1000 \mathrm{~h}$ of $5 \%$ salt spray for $\mathrm{Mg}_{2} \mathrm{Si}$ whereas the corrosion initiated after 300-600h for stainless steel. The corrosion potential for $\mathrm{Mg}_{2} \mathrm{Si}$ in aluminum alloys is more positive than that of pure $\mathrm{Mg}$ as studied by Birbilis et.al [33]. This intermetallic $\mathrm{Mg}_{2} \mathrm{Si}$ has a high melting point and hardness [34-36].

In the present work, it is expected that $\mathrm{Mg}$ dissociates $\mathrm{SiO}_{2}$ into $\mathrm{Mg}_{2} \mathrm{Si}$ and $\mathrm{MgO}$ at the sintering temperatures using Spark Plasma Sintering technique (SPS) there by forming an insitu composite of $\mathrm{Mg}_{2} \mathrm{Si}+\mathrm{Mg}$ as per the following reaction [29]:

$$
4 \mathrm{Mg}+\mathrm{SiO}_{2} \rightarrow \mathrm{Mg}_{2} \mathrm{Si}+2 \mathrm{MgO} \quad \Delta \mathrm{G}_{600^{\circ} \mathrm{C}}=-333.37 \frac{\mathrm{kJ}}{\mathrm{mol}}
$$

With the fine blend of nano-silica into the $\mathrm{Mg}$ matrix, it is expected to have uniformly distributed $\mathrm{Mg}_{2} \mathrm{Si}$ in the $\mathrm{Mg}$ matrix. In this article, we summarize our observations on the 
synthesis, mechanical properties and general corrosion behavior targeting biomedical applications.

\section{Materials and Methods}

2.1. Materials

Pure magnesium $(\mathrm{Mg})$ powder of $99.8 \%$ purity with an average particles size of $44 \mu \mathrm{m}$, and silica $\left(\mathrm{SiO}_{2}\right)$ nano powders of $99.9 \%$ purity with a size range of $10-20 \mathrm{~nm}$ were used as the base material and reinforcement respectively.

\subsection{Synthesis}

Pure $\mathrm{Mg}$ and 2.5 wt.\% $\mathrm{SiO}_{2}$ reinforced magnesium nanocomposites were synthesized using mechanical mixing/crushing and sintered using SPS. SPS experiments have been carried out using a Dr. Sinter 515S Syntex (Fuji Electronic Industrial Co., Japan) belonging to the "Plateforme CNRS de Frittage Ile de France" (ICMPE, Thiais, France). Pre-weighed amounts of pure $\mathrm{Mg}$ powder and $\mathrm{SiO}_{2}$ nano-powders were carefully blended for $1 \mathrm{~h}$ using a mortar and pestle. The blended powder mixtures were first pre-compacted under a pressure of $100 \mathrm{MPa}$, and then sintered using SPS at a temperature of $585^{\circ} \mathrm{C}$ under a pressure of $60 \mathrm{MPa}$ for $10 \mathrm{~min}$ in the form of cylindrical pellets of $10 \mathrm{~mm}$ in diameter and $3 \mathrm{~mm}$ thickness.

\subsection{Microstructural Characterizations}

2.3.1. X-ray Diffraction at room temperature and in-situ high-temperature measurements

X-ray Diffractometer (Philips) using cobalt source with a voltage of $40 \mathrm{kV}$ and tube current of $20 \mathrm{~mA}$ was used to characterize the phases formed after SPS. A $20^{\circ}-120^{\circ}$ range of diffraction angle measurement was considered using a scan rate of $0.01 \%$. For high temperature X-Ray Diffraction (HT-XRD) measurements, Bruker D8 Advance instrument with copper source was used. The generator voltage was set to $40 \mathrm{kV}$ and the current was set to $40 \mathrm{~mA}$. A 5 
${ }^{\circ} \mathrm{C} / \mathrm{min}$ heating rate was used and a step size of $0.5 \mathrm{~s}$ to record the scans sweeping from $20^{\circ}$ $100^{\circ}$ in $\mathrm{N}_{2}$ atmosphere.

\subsubsection{Differential Scanning Calorimetry}

A Differential Scanning Calorimeter (DSC) from NETSZCH, model 404C was used. The DSC response was recorded under argon flow of $60 \mathrm{cc} / \mathrm{min}$ with samples weighing approximately $10 \mathrm{mg}$. In all experiments, the samples were heated at $10^{\circ} \mathrm{C} / \mathrm{min}$ from ambient temperature $25{ }^{\circ} \mathrm{C}$ to $500{ }^{\circ} \mathrm{C}$. The tests were conducted for two repeatable readings.

\subsubsection{Density measurements}

The density of two sintered samples was measured using a Helium gas pycnometer. 20 measurements have been taken on each sample to get a good statistical evaluation.

\subsubsection{Optical and scanning electron micrographs}

To conduct microstructural characterizations, specimens were polished up to 4000 grit paper and then surfaces were given a finishing with diamond paste up to $1 / 4 \mu \mathrm{m}$. Optical micrographs were taken on the samples using ZEISS Axio Observer inverted microscope after mechanical polishing and etching with acetic-picral. Macrographs of the corroded surfaces were recorded using a ZEISS Stemi 2000C stereo microscope. A scanning electron microscope (JEOL 7800F) equipped with an energy dispersive spectrometer (EDS) was used to study the microstructure, and the precipitates of $\mathrm{Mg}_{2} \mathrm{Si}$ in the processed samples.

\subsection{Microhardness and elastic modulus}

Micro-indentation experiments were carried out on flat and polished specimens at room temperature using a CSM 2-107 Tester using a pyramidal Vickers indenter. The indentation loads from 0.1 to $25 \mathrm{~N}$ and the loading rates between $0.5 \mathrm{~N} / \mathrm{min}$ and $300 \mathrm{~N} / \mathrm{min}$ were available on the instrument range. For this experiment, $0.5 \mathrm{~N}$ load and a loading rate of $1 \mathrm{~N} / \mathrm{min}$ was applied. The indenter was maintained at the maximum load during $5 \mathrm{~s}$. The tests were conducted for 10 repeatable readings to ensure reproducibility. Oliver-Pharr method was 
applied to the Load Vs Displacement curves to determine the microhardness and the Elastic modulus.

\subsection{Corrosion behavior}

Electrochemical measurements were done using Voltalab instrument. The standard threeelectrode setup was used: i.e. saturated calomel electrode as reference, platinum as counter and the test sample mounted in a resin as working electrodes. Potentiodynamic polarization tests using Phosphate Buffer Saline (PBS) solution at controlled temperature of $37{ }^{\circ} \mathrm{C}$ was used and the scan rate adopted was $1 \mathrm{mV} / \mathrm{s}$ ranging from $-2.5 \mathrm{~V}$ to $-0.5 \mathrm{~V}$. The composition of PBS solution is given in [37].

Minimum of three trials for each sample were conducted. The samples before corrosion were polished using $\mathrm{SiC}$ abrasive papers to 4000 grit and then washed with ethanol. SEM coupled with energy dispersive spectrometry was used to record the microstructure of corroded samples.

\section{Results and discussion}

SPS sintered samples were tested for their physical properties, mechanical properties and their corrosion behavior. In the following sections, we summarize different observations of those properties:

\subsection{Microstructural characterization}

3.1.1. X-ray diffraction at room temperature

The XRD patterns of the sintered samples are shown in Figure 1. For both samples, the

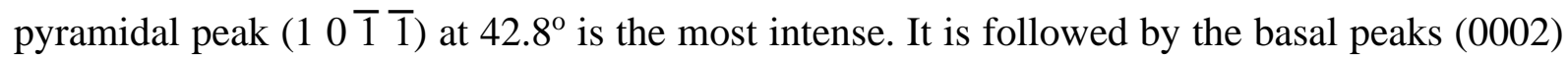

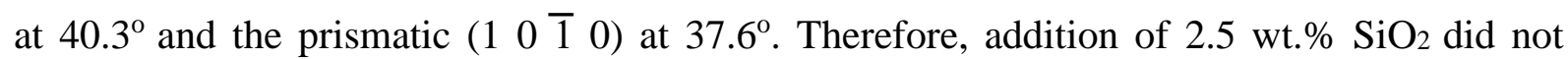
affect the texture of pure magnesium. 
For sintered $\mathrm{Mg}-2.5$ wt.\% $\mathrm{SiO}_{2}$ diffractogram, $\mathrm{Mg}_{2} \mathrm{Si}$ peaks are observed, as identified by their diffraction peaks at $28.2^{\circ}$ and $46.8^{\circ}$ corresponding to (111) and (002) diffraction planes respectively. The presence of $\mathrm{MgO}$ peaks at $50.4^{\circ}$ and $88^{\circ}$ could be seen for both the samples.

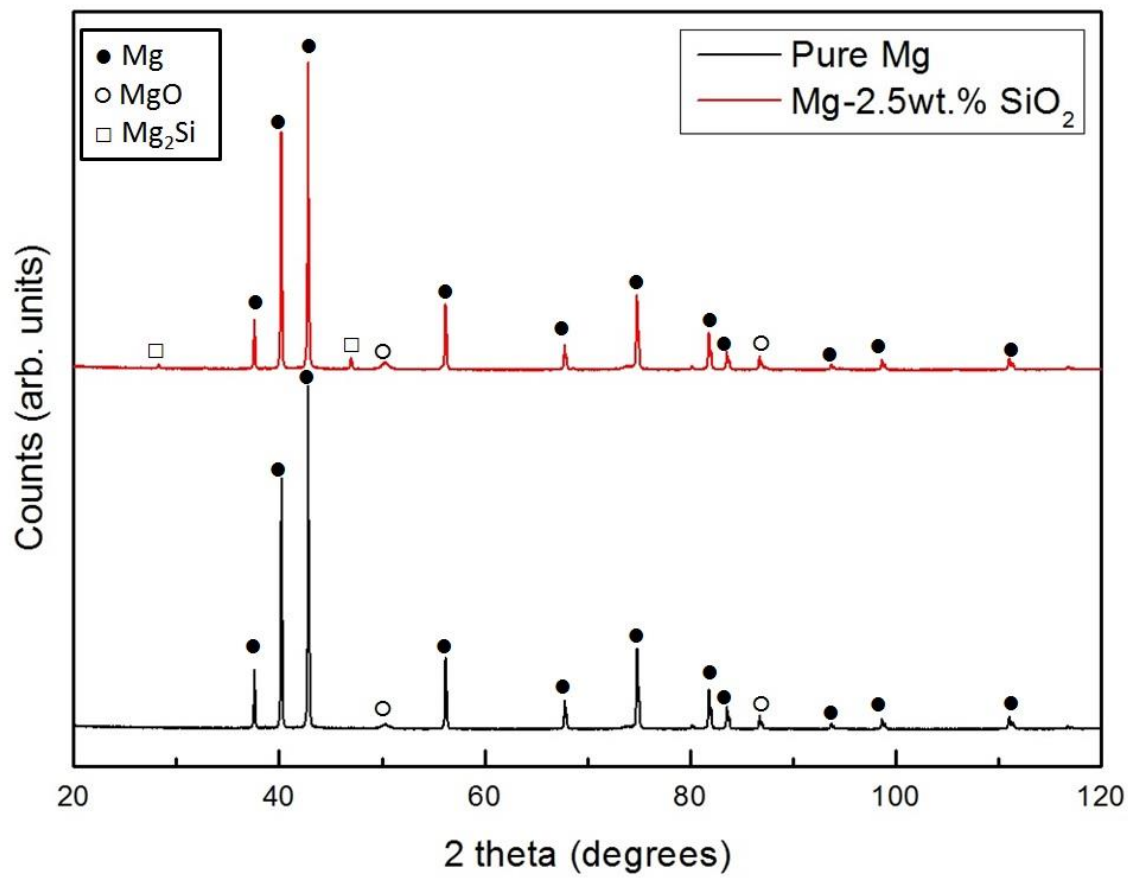

Figure 1: X-ray diffractogram of sintered samples

\subsubsection{In-situ High Temperature X-ray diffraction}

High temperature XRD peaks to follow the formation of $\mathrm{Mg}_{2} \mathrm{Si}$ and $\mathrm{MgO}$ during sintering are plotted in Figure 2. The peak for $\mathrm{Mg}_{2} \mathrm{Si}$ starts to form at $470^{\circ} \mathrm{C}$ and the intensity increases with temperature, as seen by the peak at $2 \theta=52^{\circ}$. Presence of $\mathrm{MgO}$ peaks could be seen at all temperatures, their intensity also increases with temperature. The first three intense peaks of pure magnesium start to decrease in intensity with the formation of $\mathrm{Mg}_{2} \mathrm{Si}$ and $\mathrm{MgO}$. One peak for $\mathrm{SiO}_{2}$ were seen at low temperature and it is indexed for $2 \theta=26^{\circ}$. 


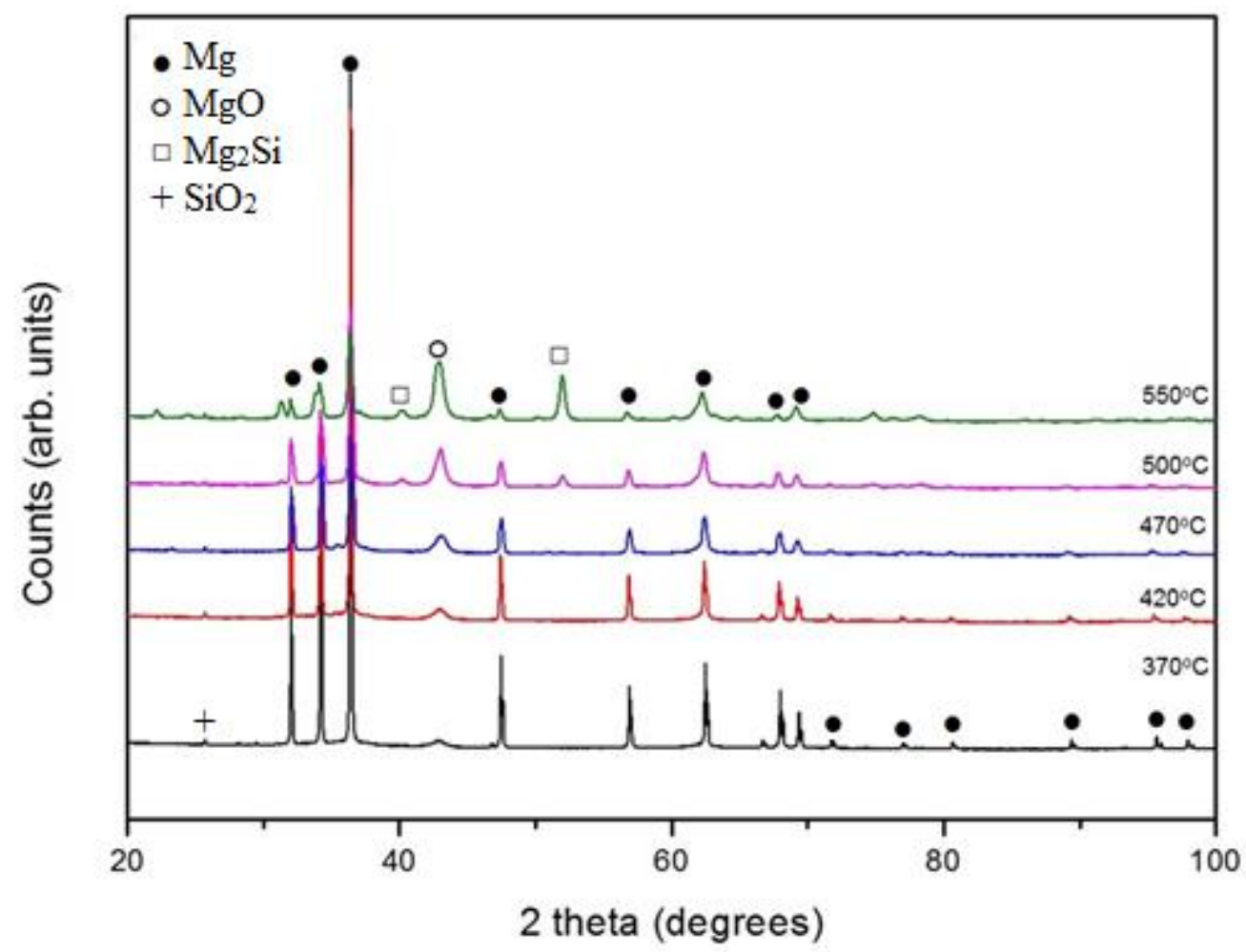

Figure 2: HT-XRD of $\mathrm{Mg}-2.5 \mathrm{wt} . \% \mathrm{SiO}_{2}$ blended powders

\subsubsection{Differential Scanning Calorimetry}

For an estimation of sintering temperature and the possible reactions between blended powders, DSC technique was employed to study the formation of $\mathrm{Mg}_{2} \mathrm{Si}$ and $\mathrm{MgO}$. The DSC thermograms of pure $\mathrm{Mg}$ and $\mathrm{Mg}-\mathrm{SiO}_{2}$ powders are plotted on Figure 3. For pure $\mathrm{Mg}$, there are no peaks detected in the thermogram. For $\mathrm{Mg}_{-} \mathrm{SiO}_{2}$, they exhibit a downward trend throughout the acquisition range of temperature except at the vicinity of an exothermic peak split into two peaks. These peaks appear at $420^{\circ} \mathrm{C}$ and $440^{\circ} \mathrm{C}$ with an onset at $411^{\circ} \mathrm{C}$ and $430^{\circ} \mathrm{C}$ respectively. Both peaks are sharp and the first one is larger than the second. The trend exhibited in two trials is the same, except that a slightest change in the mass of the samples led to different DSC values, but the peak positions and the area under the peak values are same for both trials. DSC analysis performed on $\mathrm{Mg}-2.5$ wt.\% (micro) $\mathrm{SiO}_{2}$ with similar conditions showed only one exothermic peak at $470^{\circ} \mathrm{C}$. This peak was broad that started at $440^{\circ} \mathrm{C}$ and appears till $500^{\circ} \mathrm{C}$. There were no detectable phase transformations before and 
after these peaks in the temperature measurement range. A larger endothermic peak would appear at $650^{\circ} \mathrm{C}$ that determines melting, but this was beyond the acquisition range. Both trials were repeatable and showed similar trend.

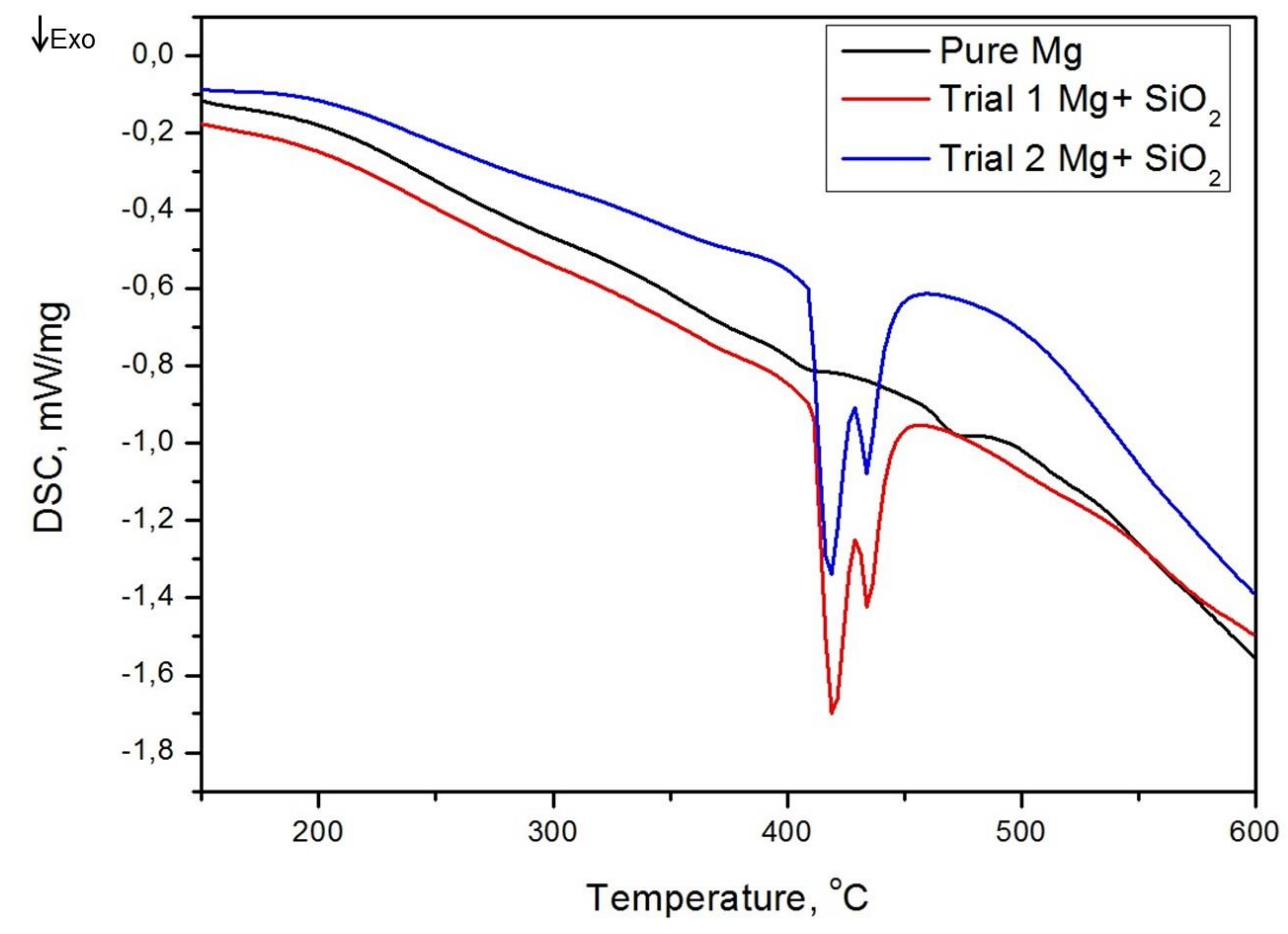

Figure 3: DSC thermograms of pure $\mathrm{Mg}$ and blended $\mathrm{Mg}-2.5$ wt. $\% \mathrm{SiO}_{2}$ powders

The DSC results obtained are in good agreement with the analysis done by Kondoh et.al where they studied solid-state synthesis of $\mathrm{Mg}_{2} \mathrm{Si}$ and $\mathrm{MgO}$ using elemental $\mathrm{AZ3} 3$ and $\mathrm{SiO}_{2}$ glass powder mixture [28]. The DSC curve in their studies showed an exothermic peak at $457^{\circ} \mathrm{C}$. In the current study an exothermic peak is observed in all the repeated measurements. This peak is attributed to an in-situ reaction of magnesium with silica that has taken place to form $\mathrm{Mg}_{2} \mathrm{Si}$ but a peak-split could be seen. It is considered that they are not two peaks but one peak split into two as there is no available literature for the existence of two peaks that could correspond to two different reactions for $\mathrm{Mg}_{-} \mathrm{SiO}_{2}$ composite. There is only one reaction that takes place and it is the formation of $\mathrm{Mg}_{2} \mathrm{Si}$. Since nano-silica is used in this case, the reaction takes place slightly earlier, at $410^{\circ} \mathrm{C}$ and it commences upto $460^{\circ} \mathrm{C}$. The first peak is attributed 
to $\mathrm{Mg}_{2} \mathrm{Si}$ formation due to deformation of the particles done before DSC. The second peak is attributed to the solid state reaction of residual $\mathrm{Mg}$ with residual $\mathrm{SiO}_{2}$ to form $\mathrm{Mg}_{2} \mathrm{Si}$ at a slightly higher temperature. Mechanical milling induced sub-processes were studied before on the formation of nanocrystalline $\mathrm{Mg}_{2} \mathrm{Si}$ [38]. As the peaks for $\mathrm{Mg}_{2} \mathrm{Si}$ in HT-XRD appear after $470^{\circ} \mathrm{C}$ in Figure 2, it can be deduced that the reaction product in DSC after the experiment is $\mathrm{Mg}_{2} \mathrm{Si}$. Slightly higher temperature $457^{\circ} \mathrm{C}$ in the results obtained by Kondoh et.al [28] could be due to the fact that, it was an alloy AZ31 instead of pure magnesium and also because $\mathrm{SiO}_{2}$ was a glass powder mixture in their study. DSC analysis done by Myalska et.al on a powder mixture of granulated $\mathrm{Mg}$ and nanosized silica showed an exothermic peak at $515^{\circ} \mathrm{C}$. An increase in the temperature could be because the initial powders were not mixed properly [29]. Also a 1:1 powder mixture was considered that delayed the onset of phase formation. By adopting mechanical alloying process, Lu et.al studied the formation of nanocrystalline $\mathrm{Mg}_{2} \mathrm{Si}$ using elemental $\mathrm{Mg}$ and Si powders [24]. They observed an exothermic peak at $190^{\circ} \mathrm{C}$ after $10 \mathrm{~h}$ of mechanical alloying and the formation of $\mathrm{Mg}_{2} \mathrm{Si}$ took place at the same temperature for increased milling time. Because of the attrition between the powders, this process introduced lot of defects and resulted in decreasing the activation energy for diffusion.

\subsubsection{Density}

Using SPS technique, highly dense $\mathrm{Mg}$ and $\mathrm{Mg}-\mathrm{SiO}_{2}$ composites were synthesized. The density measurements are shown in Table 1. The experimental densities are always higher than the theoretical predicted density for pure magnesium $(1.7 \mathrm{~g} / \mathrm{cc})$. This is due to the presence of $\mathrm{MgO}$ in the starting powders and also due to the formation of $\mathrm{MgO}$ during sintering process. $\mathrm{Mg}-2.5 \mathrm{wt} \% \mathrm{SiO}_{2}$ exhibits maximum experimental density value due to the incorporation of $\mathrm{SiO}_{2}$, which is only approx. $1 \%$ greater than that of pure $\mathrm{Mg}$.

The higher experimental density values for both samples are attributed to the presence of low $\mathrm{MgO}$ content (about 2-3 vol.\%) present on all the sintered samples. $\mathrm{MgO}$ has a density of 3.58 
$\mathrm{g} / \mathrm{cm}^{3}$ and its presence has certainly increased the overall density of the sintered samples. Further, a marginal increase in the density value of the composite is due to the presence of dense $\mathrm{Mg}_{2} \mathrm{Si}$ particles in the sample. The density of $\mathrm{Mg}_{2} \mathrm{Si}$ is $1.99 \mathrm{~g} / \mathrm{cm}^{3}$, which is slightly higher than that of pure magnesium.

\subsubsection{Optical Microscopy}

The optical observations of sintered samples etched using acetic-picral and their corresponding grain size histograms calculated for 500 grains are shown in Figure 4. Figure 4a shows an optical micrograph of pure $\mathrm{Mg}$ sintered at $585{ }^{\circ} \mathrm{C}$. The corresponding grain size histogram is shown in Figure $4 \mathrm{~b}$. The average grain size measured using ImageJ software is $18 \mu \mathrm{m}$ for this sample. Figure $4 \mathrm{c}$ shows an optical micrograph of $\mathrm{Mg}-2.5 \mathrm{wt} . \% \mathrm{SiO}_{2}$ sintered at $585^{\circ} \mathrm{C}$ etched using acetic-picral. It's grain size is $15 \mu \mathrm{m}$. The optical micrographs for both samples show a well sintered microstructure. It is suspected that, $\mathrm{Mg}_{2} \mathrm{Si}$ is formed along the grain boundaries and some within the grains, as characterized by the dark region along the grain boundaries due to etching. This will be later confirmed by SEM-EDS analysis. It can be interpreted based on these observations that the addition of nano silica did not affect greatly in reducing the grain size of magnesium.
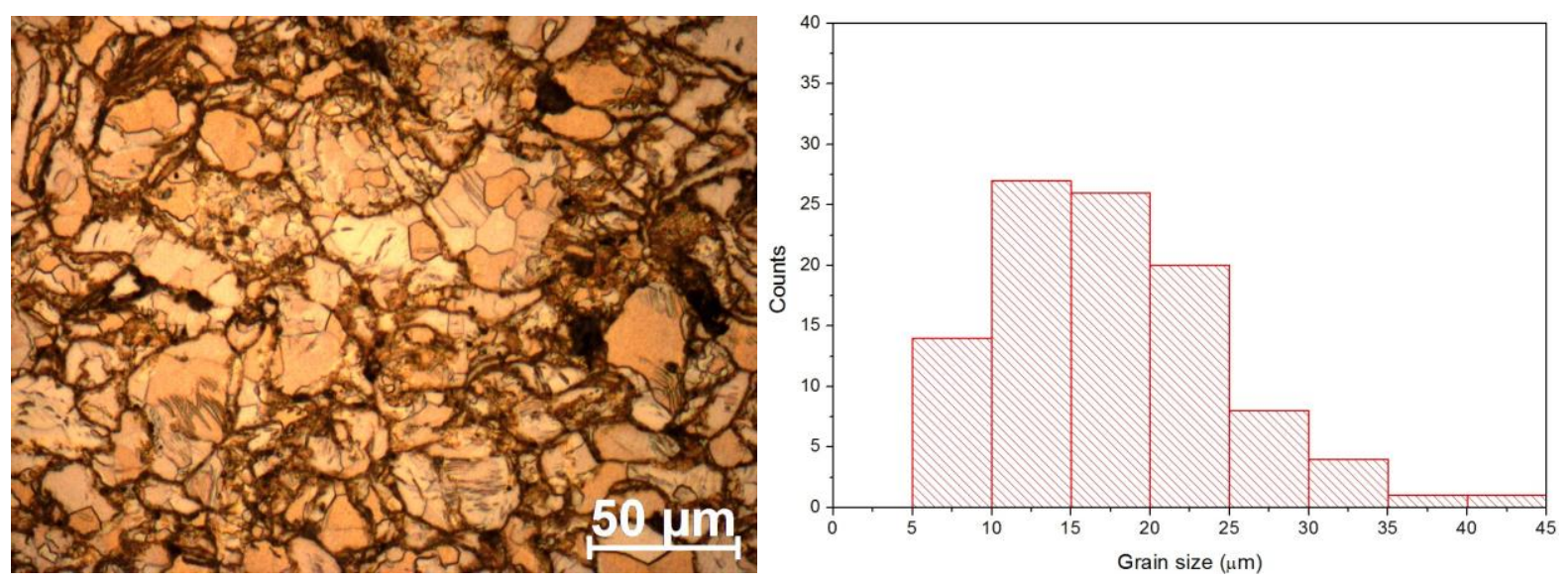
(a) Pure Mg
(b) Grain size histogram for pure $\mathrm{Mg}$ 


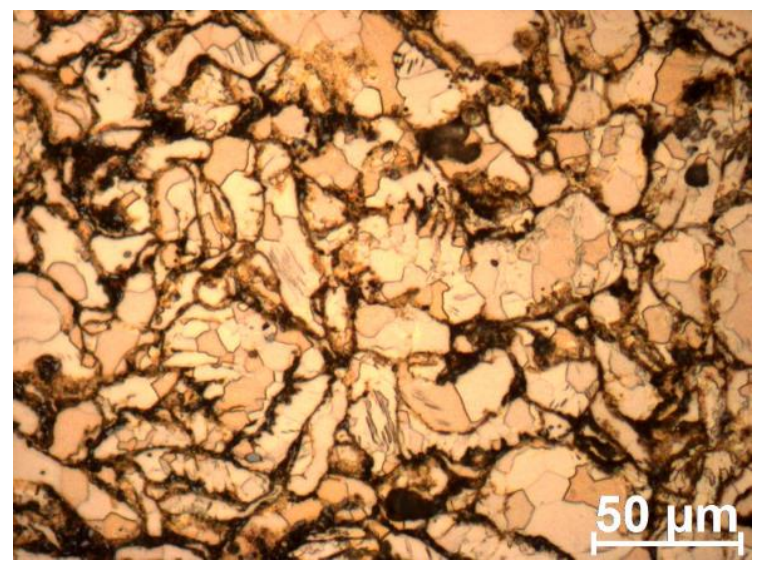

(c) $\mathrm{Mg}-2.5$ wt. $\% \mathrm{SiO}_{2}$

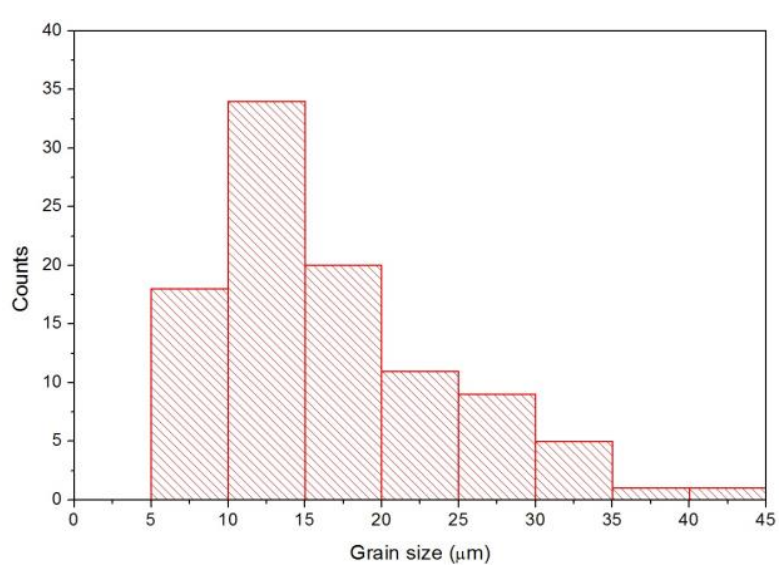

(d) Grain size histogram for Mg-2.5 wt. $\% \mathrm{SiO}_{2}$

Figure 4: Optical micrographs and histograms for $\mathrm{Mg}$ and $\mathrm{Mg}-2.5$ wt. $\% \mathrm{SiO}_{2}$ sintered samples

\subsubsection{Scanning electron micrography}

Figure 5 shows a BSE image of $\mathrm{Mg}-2.5$ wt. $\% \mathrm{SiO}_{2}$ sintered at $585^{\circ} \mathrm{C}$ and the EDS maps indicating the presence of $\mathrm{Si}, \mathrm{Mg}$ and $\mathrm{O}$. SEM and EDS analysis on the samples sintered at $585^{\circ} \mathrm{C}$ shows the uniform distribution of $\mathrm{Si}$ and the presence of $\mathrm{Mg}_{2} \mathrm{Si}$ and $\mathrm{MgO}$ along the particle boundaries. These phases are identified as it can be seen from the maps the corresponding elemental concentrations. For $\mathrm{MgO}$ phase, the elemental maps are highlighted for $\mathrm{Mg}$ and $\mathrm{O}$. For $\mathrm{Mg}_{2} \mathrm{Si}$ phase, the corresponding spots are highlighted with respective color. Also, point scans have bene made on these phases and the results indicate the elemental presence in individual phases. XRD results support the presence of these phases. Hence, it confirms our initial hypothesis of $i n$-situ reaction of $\mathrm{Mg}$ with $\mathrm{SiO}_{2}$ at higher temperatures. The silica particles were nano-sized and due to blending prior to compaction and sintering, any agglomeration of this reinforcing material was not present. 

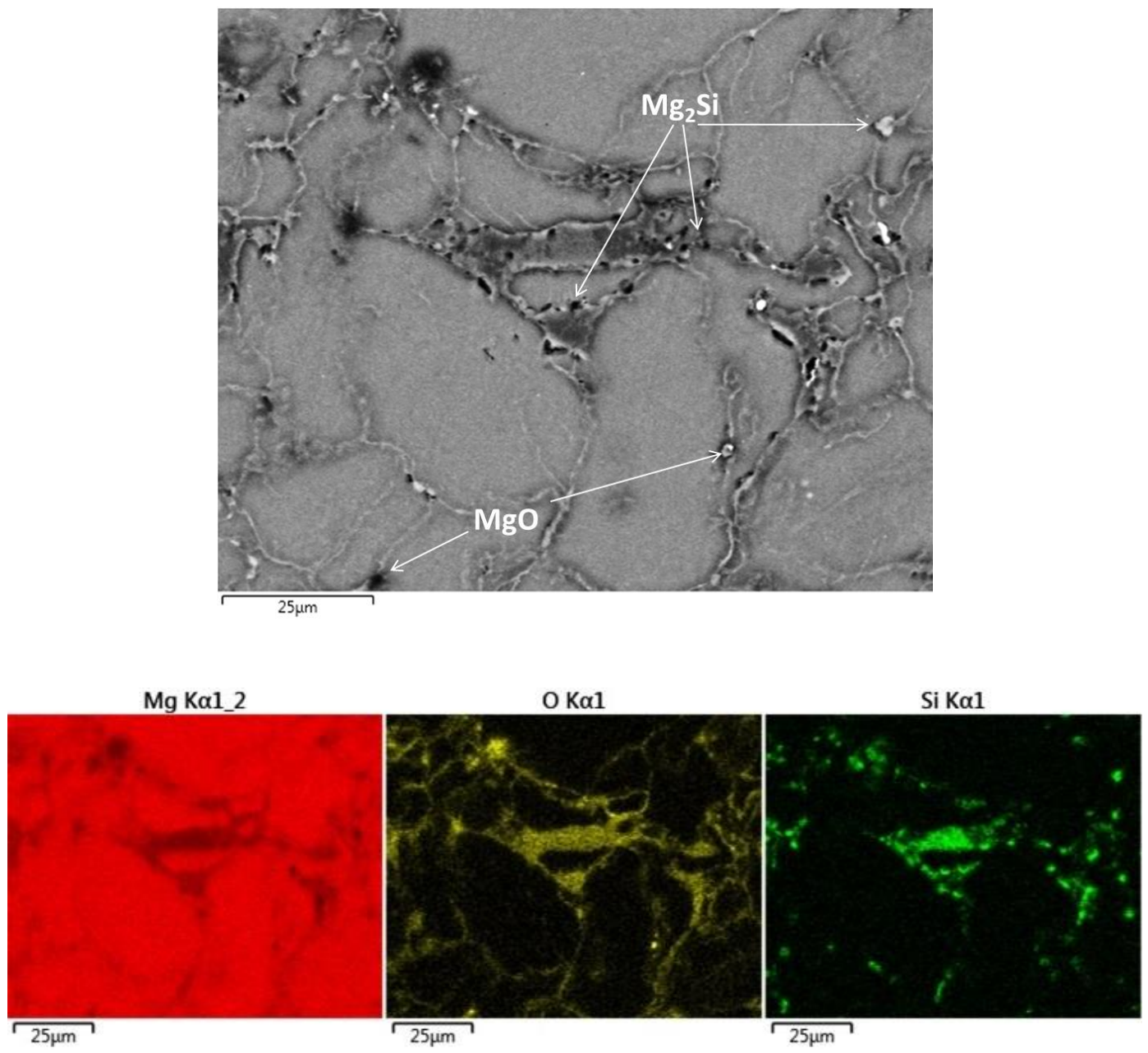

Figure 5: EDS maps for $\mathrm{Mg}, \mathrm{O}$ and $\mathrm{Si}$ and its corresponding BSE image for Mg-2.5 wt.\% $\mathrm{SiO}_{2}$ composite

\subsection{Mechanical Characterizations}

Table 1 shows the microhardness results for pure $\mathrm{Mg}$ and $\mathrm{Mg}-2.5 \mathrm{wt} . \% \mathrm{SiO}_{2}$ after sintering. $\mathrm{Mg}-2.5 \mathrm{wt} . \% \mathrm{SiO}_{2}$ sintered composite has an increased microhardness value than the pure $\mathrm{Mg}$ material. This could be due to the presence of $\mathrm{Mg}_{2} \mathrm{Si}$. $\mathrm{Mg}_{2} \mathrm{Si}$ being an intermetallic compound with high hardness, low density and a high melting temperature [35]. Hard nano-silica [36] particles distributed uniformly due to grinding and sintering led to a dispersion strengthened $\mathrm{Mg}_{2} \mathrm{Si}-\mathrm{Mg}$ composite with the formation of intermetallic $\mathrm{Mg}_{2} \mathrm{Si}$ that has a good interface with $\mathrm{Mg}$ matrix. Hence the hardness of $\mathrm{SiO}_{2}$ reinforced composite is higher than that of pure magnesium. 
Hardness and elastic modulus values are obtained from micro indentation hardness tester using Oliver-Pharr method with $500 \mathrm{mN}$ of constant load and a dwell time of $5 \mathrm{~s}$. Hardness values show a 39 percent increase for $\mathrm{Mg}-2.5$ wt. $\% \mathrm{SiO}_{2}$ composite as compared to pure $\mathrm{Mg}$. The resulting load-displacement curves are shown in Figure 6. Using these curves, reduced elastic modulus was calculated. These values are in the range of 45-48 GPa, which is in close comparison to the elastic modulus of cortical bone which is 10-20 GPa [2].

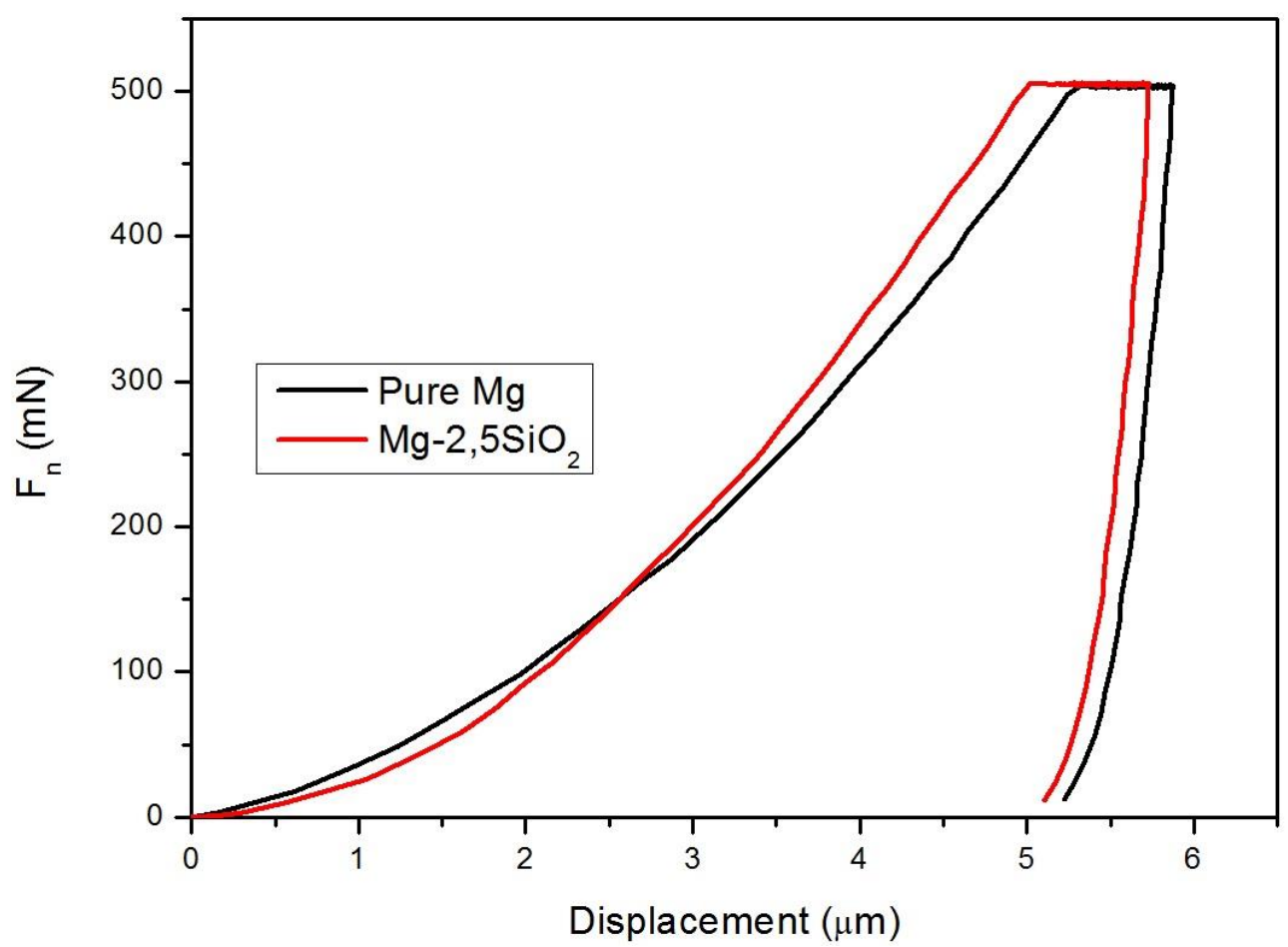

Figure 6: Load-displacement curves for sintered magnesium and it's composite Apart from corrosion resistance, another important property of a biomaterial targeting orthopedic applications is elastic modulus. Conventional implants made of titanium and stainless steels have elastic modulus in the order of 100-200 GPa [2]. Because of the difference in the stiffness of an implant and the bone, a phenomenon called stress shielding occurs. This leads to decrease in bone mass, which is known as bone resorption. Also implant materials made of magnesium is biodegradable, which rules out the need for its removal during second surgery. Thus the synthesized in-situ $\mathrm{Mg}_{2} \mathrm{Si}-\mathrm{Mg}$ composite with its properties 
similar to that of natural bone has the potential to replace commercially available expensive implants. The composite does not show increased elastic moduli with the addition of $\mathrm{SiO}_{2}$ or the in-situ precipitation of $\mathrm{Mg}_{2} \mathrm{Si}$. This is rather beneficial as the elastic modulus of bone is similar to that of pure $\mathrm{Mg}$.

\subsection{Potentiodynamic Polarization Test}

Figure 7 shows the potentiodynamic polarization curves plotted for pure $\mathrm{Mg}$ and $\mathrm{Mg}-2.5 \mathrm{wt} . \%$ $\mathrm{SiO}_{2}$. Immediately after immersion in the PBS solution, the voltage sweep was carried out to measure the current for freshly prepared specimens. $\mathrm{Mg}-2.5 \% \mathrm{SiO}_{2}$ shows greater corrosion potential and lower corrosion current density compared with pure magnesium. The polarization parameters are tabulated in Table 1. As seen in the table, the corrosion current for the silica reinforced composite is two orders of magnitude lower than for pure magnesium. Also the corrosion rate calculated using tafel slope plot is $0.2 \mathrm{~mm} / \mathrm{y}$ in comparison with 35.2 $\mathrm{mm} / \mathrm{y}$ for pure magnesium. This shows the improvement in the corrosion behavior with the reinforcement of nano silica.

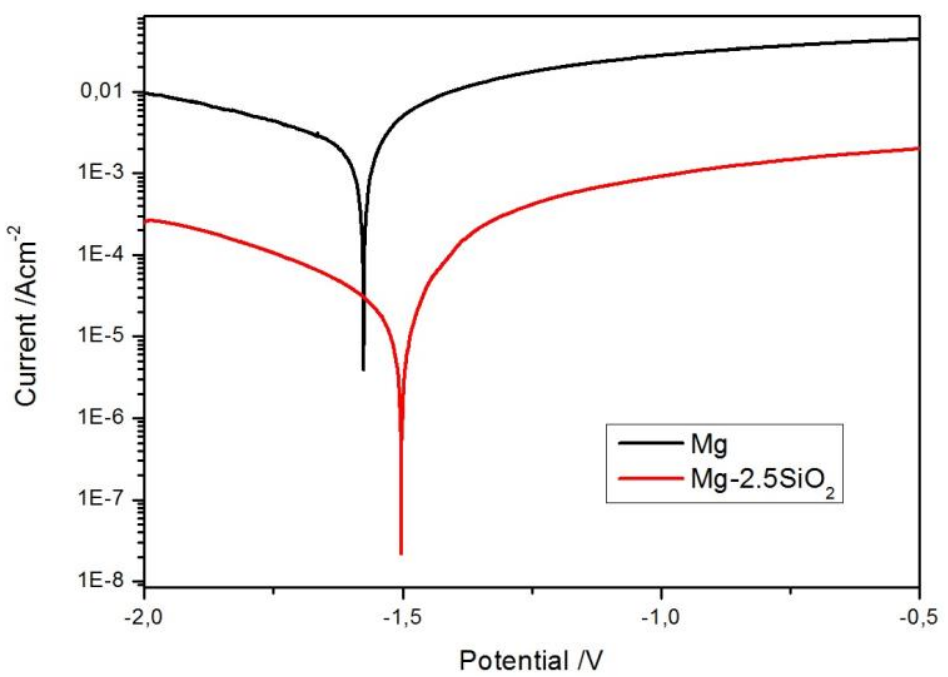

Figure 7: Potentiodynamic Polarization Curves for sintered pure $\mathrm{Mg}$ and $\mathrm{Mg}-2.5$ wt. $\% \mathrm{SiO}_{2}$

Table 1: Measurements related to density, hardness and corrosion

Material Density Hardness Corrosion rate in PBS solution at $37{ }^{\circ} \mathrm{C}$




\begin{tabular}{|c|c|c|c|c|c|}
\hline & (g/cc) & & $\mathbf{E}_{\text {corr }}(\mathbf{m V})$ & $\begin{array}{c}\mathbf{i}_{\text {corr }} \\
\left(\mathbf{m A} / \mathrm{cm}^{2}\right)\end{array}$ & $\begin{array}{l}\text { Corrosion rate } \\
\qquad(\mathbf{m m} / \mathbf{y})\end{array}$ \\
\hline $\mathrm{Mg}$ & $1.789 \pm 0.002$ & $50.1 \pm 2.9$ & -1576.3 & 3.0119 & 35.2 \\
\hline $\mathrm{Mg}-2.5 \mathrm{SiO}_{2}$ & $1.822 \pm 0.007$ & $69.4 \pm 4.5$ & -1503.2 & 0.0170 & 0.2 \\
\hline
\end{tabular}

Figure 8 shows the macrograph of the corroded surfaces of pure $\mathrm{Mg}$ and $\mathrm{Mg}-2.5$ wt.\% $\mathrm{SiO}_{2}$ after potentiodynamic polarization test. The degradation layer with a certain thickness that appears as whitish gray spread across the complete surface of pure magnesium. This layer is fragile and it could easily be chipped off. On the other hand in the case of $\mathrm{Mg}-2.5$ wt. $\% \mathrm{SiO}_{2}$, the entire surface was not corroded. Corrosion took place in certain areas that are well connected, leaving aside some areas uncorroded.

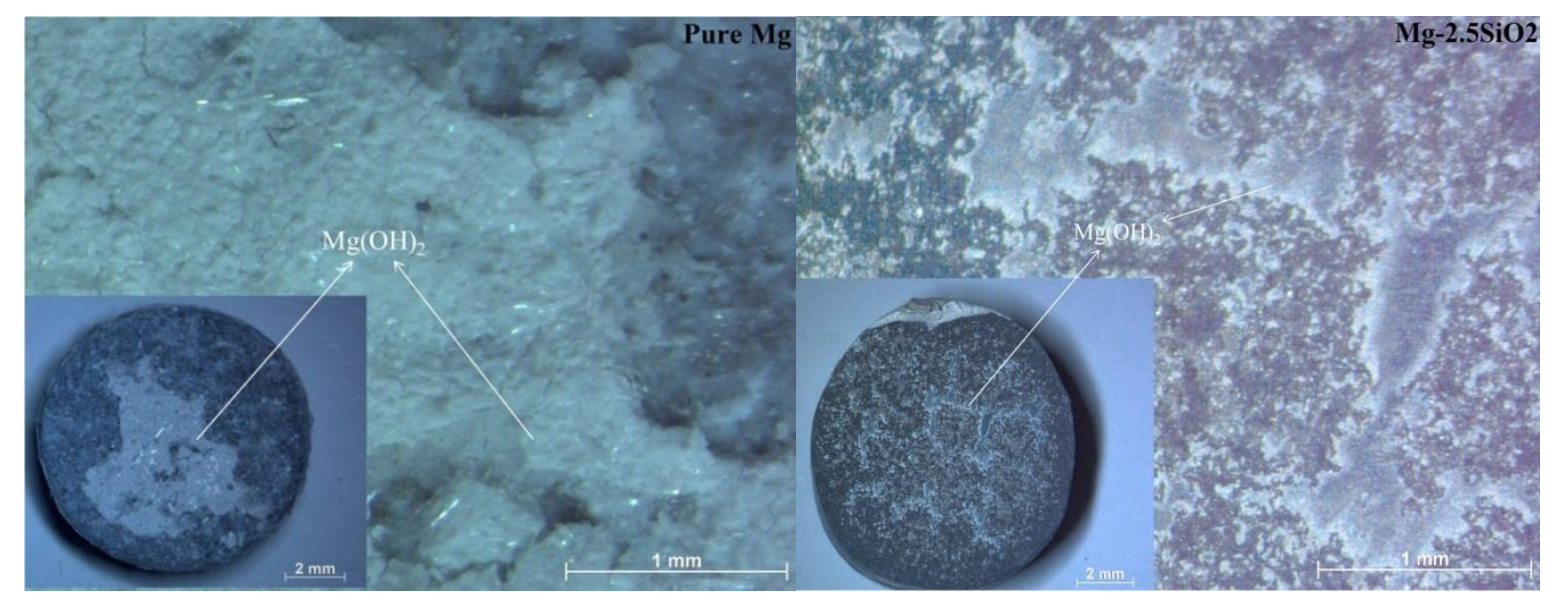

Figure 8: Macrograph of the corroded surfaces of pure $\mathrm{Mg}$ and $\mathrm{Mg}-2.5$ wt.\% $\mathrm{SiO}_{2}$ after potentiodynamic polarization test

To study the corrosion morphology in detail, SEM analysis of corroded samples after potentiodynamic polarization studies was carried out and their morphology is shown in Figure 9. In the case of pure magnesium, as seen in Figure 9a, preferential oxidation of grain boundaries was observed along with the grain interiors oxidizing uniformly, the corrosive products were deposited everywhere in the sample. These products do not have a definitive 
morphology and they are irregular. In the case of $\mathrm{Mg}-2.5 \mathrm{wt} \% \mathrm{SiO}_{2}$, these products mostly form globular shape and they are not as dispersed as that of pure magnesium.

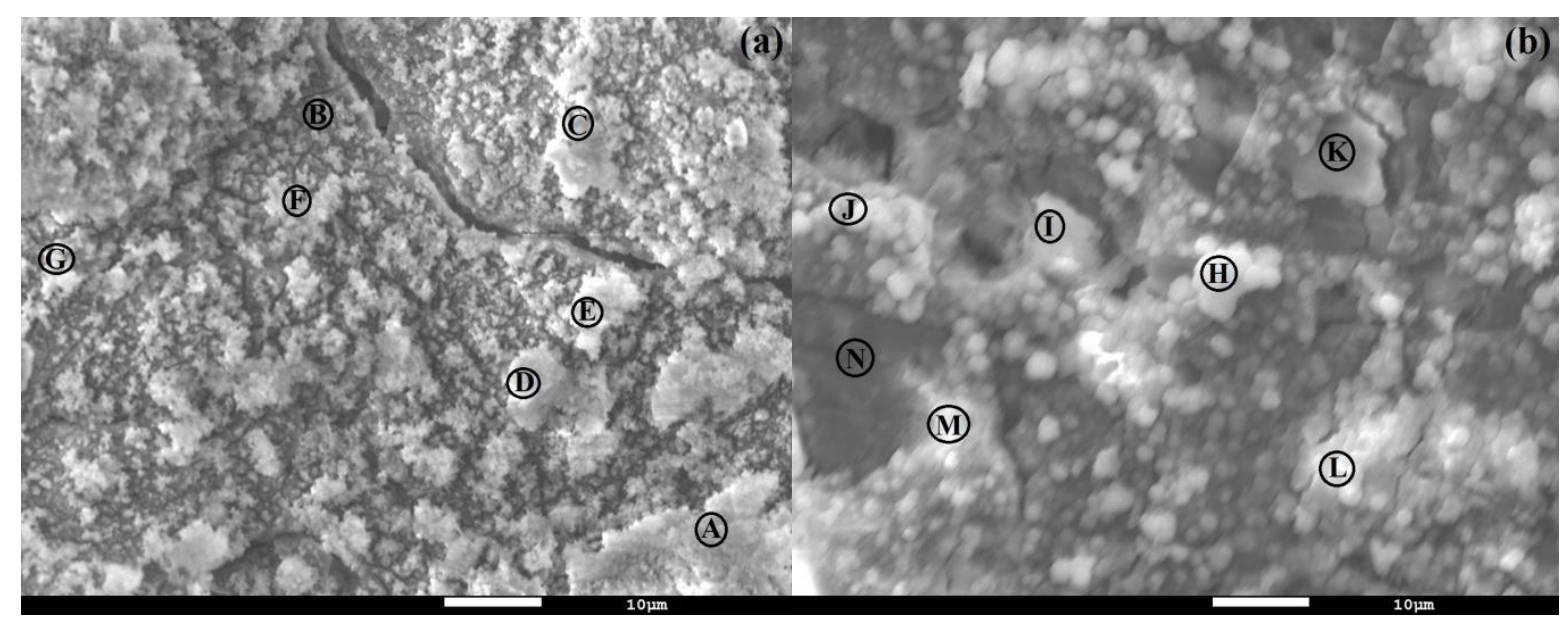
(a) Pure Mg
(b) $\mathrm{Mg}-2.5$ wt. $\% \mathrm{SiO}_{2}$

Figure 9: SEM images of corroded surfaces of $\mathrm{Mg}$ and $\mathrm{Mg}-2.5$ wt. $\% \mathrm{SiO}_{2}$ sintered samples A detailed EDS analysis is presented in Table 2. For pure magnesium corroded sample, the surface is mainly comprised of $\mathrm{Mg}, \mathrm{O}, \mathrm{P}$ and $\mathrm{Cl}$. The corrosion products could be a mixture of $\mathrm{Mg}(\mathrm{OH})_{2}, \mathrm{MgCl}_{2}$ and $\mathrm{MgHPO}_{4}$. But in the case of $\mathrm{Mg}-\mathrm{SiO}_{2}$ composite, the corroded surface is only comprised of $\mathrm{Mg}, \mathrm{O}, \mathrm{P}$ and $\mathrm{Si}$. $\mathrm{Cl}^{-}$is not detected on the corroded products and it could be concluded that $\mathrm{MgCl}_{2}$ has not been formed. The atomic percent ratio of $\mathrm{Mg}$ and $\mathrm{O}$ on most of the corroded products is close to $1: 2$ corresponding to $\mathrm{Mg}(\mathrm{OH})_{2}$ composition.

Table 2: EDS analysis of $\mathrm{Mg}$ and $\mathrm{Mg}-2.5$ wt. $\% \mathrm{SiO}_{2}$ composites. The values are in weight percent

\begin{tabular}{|lllllll|}
\hline Material & Spot & Mg & O & Si & P & Cl \\
\hline Mg & A & 28.5 & 49.6 & 19.5 & 2.4 \\
& B & 30.1 & 38.2 & 28.6 & 3 \\
& C & 26.3 & 52.3 & 20.6 & 0.9 \\
& D & 25.6 & 54.5 & 18.5 & 1.5 \\
& & & & & & \\
\hline
\end{tabular}




\begin{tabular}{|c|c|c|c|c|c|c|}
\hline & $\mathrm{E}$ & 28.1 & 50.3 & & 19.9 & 1.7 \\
\hline & $\mathrm{F}$ & 24.4 & 57.1 & & 16.8 & 1.7 \\
\hline & $\mathrm{G}$ & 26.1 & 52.8 & & 18.6 & 2.5 \\
\hline & Average & 27.0 & 50.7 & & 20.4 & 1.9 \\
\hline $\mathrm{Mg}-2.5$ & $\mathrm{H}$ & 42.7 & 56.3 & & 1.0 & \\
\hline wt.\% & I & 45.2 & 52.7 & & 2.1 & \\
\hline $\mathrm{SiO}_{2}$ & $\mathrm{~J}$ & 41.5 & 57.6 & & 0.9 & \\
\hline & K & 52.2 & 45.9 & 0.4 & 1.5 & \\
\hline & $\mathrm{L}$ & 45.2 & 53.4 & 0.3 & 1.1 & \\
\hline & M & 44.8 & 54.3 & & 0.9 & \\
\hline & $\mathrm{N}$ & 48.4 & 50.8 & & 0.8 & \\
\hline & Average & 45.7 & 53.0 & 0.1 & 1.2 & \\
\hline
\end{tabular}

In-situ precipitated $\mathrm{Mg}_{2} \mathrm{Si}$ with its uniform distribution has improved the general corrosion behavior significantly. It is possible that these precipitates act as a barrier to further corrosion by stabilizing the hydroxide film formed on it's surface. Also, it minimized the $\alpha$-Mg content subjected to corrosion by introducing $\mathrm{Mg}_{2} \mathrm{Si}$ precipitates. As reported by Kondoh et al., according to Japanese International Standard JIS Z 2371, the corrosion process was initiated in a conventional stainless steel over $\mathrm{Mg}_{2} \mathrm{Si}$ intermetallic during a salt spray test at $35^{\circ} \mathrm{C}$ conducted for a long time[28]. Ben Hamu et al. introduced different amounts of Si to $\mathrm{Mg}$ 6Zn-0.5Mn alloy to study their corrosion behavior [31]. When the Si content is below 1 wt.\% (Chinese script type morphology of $\mathrm{Mg}_{2} \mathrm{Si}$ ), the corrosion rate was found to be higher. But when the volume fraction of silicon is higher (polygonal type morphology of $\mathrm{Mg}_{2} \mathrm{Si}$ ), the corrosion rate was low. $\mathrm{Mg}_{2} \mathrm{Si}$ is resistant to corrosion [33] as compared to pure $\mathrm{Mg}$ although, it was proven in aluminum alloys. Birbilis et al. studied several intermetallics on AA7075 and it was found that $\mathrm{Mg}_{2} \mathrm{Si}$ did not show any breakdown potential and it corroded freely above 
their $E_{\text {corr }}$ [33]. They conducted electrochemical testing of aluminum alloys via microcell method and in $\mathrm{NaCl}$ solution the corrosion potential of intermetallic $\mathrm{Mg}_{2} \mathrm{Si}$ was found to be more positive than pure $\mathrm{Mg}$ [33]. For further clear understanding of the role of intermetallic $\mathrm{Mg}_{2} \mathrm{Si}$, it is necessary to conduct microcapillary electrochemical measurements.

In a study pursued by Andreatta et al. [39] on the corrosion behavior of the intermetallics in a magnesium alloy, they found that among several intermetallics, $\mathrm{Mg}_{2} \mathrm{Si}$ showed the weakest cathodic behavior relative to the matrix. The difference in the electrochemical potential between $\mathrm{Mg}_{2} \mathrm{Si}$ and $\mathrm{Mg}$ or $\mathrm{MgO}$ and $\mathrm{Mg}$ leads to the formation of galvanic couples between these phases and the matrix. These phases are distributed uniformly throughout the matrix. The localized corrosion was not observed for the synthesized $\mathrm{Mg}_{2} \mathrm{Si}-\mathrm{Mg}$ composite. The degradation took place uniformly.

With the addition of $\mathrm{SiO}_{2}$ and the formation of $\mathrm{Mg}_{2} \mathrm{Si}$, the quantity of $\mathrm{Mg}$ decreased. Pure $\mathrm{Mg}$ undergoes rapid corrosion due to the $\mathrm{Cl}^{-}$ion from the solution that gets trapped in the surface film which is pseudo-passive. It is possible that the presence of these phases in the film reduces the porosity of the film structure and prevents $\mathrm{Cl}^{-}$ions from attacking pure $\mathrm{Mg}$ and enhances the corrosion resistance of $\mathrm{Mg}-\mathrm{Mg}_{2} \mathrm{Si}$ composite.

Hence, the addition of silica nanoparticulates is beneficial in synthesizing a bionanocomposite that can delay the degradation process as an implant in a human body.

\section{Conclusions}

Magnesium-silica based composites were prepared by powder metallurgy for in-situ synthesis of $\mathrm{Mg}_{2} \mathrm{Si}$. The existing works on micro-silica addition to $\mathrm{Mg}$ and its alloys consists of $\mathrm{Mg}_{2} \mathrm{Si}$ particles in Chinese script type or polygonal with particle sizes in the order of 10-60 $\mu \mathrm{m}$ [31]. Another study of incorporating micro $\mathrm{SiO}_{2}$ to pure $\mathrm{Mg}$ consisted of agglomeration due to increased size of $\mathrm{Mg}_{2} \mathrm{Si}$ phase. This decreases the mechanical properties of the composite 
material [40]. Also the density of the composites gets lowered if the particle size of the reinforcement is beyond a certain limit.

Hence we used nanometer silica, to not only have a uniform distribution of $\mathrm{Mg}_{2} \mathrm{Si}$ phase but also to ensure the complete conversion into $\mathrm{Mg}_{2} \mathrm{Si}$ due to an increased reactivity of nanosilica. This enhances the mechanical properties, density and the corrosion resistance. Also $\mathrm{SiO}_{2}$ nanoparticles have been extensively used for biomedical applications such as drugdelivery agents as it has greater surface properties. As this work is associated with developing Mg composites targeting biomedical applications, usage of nano-silica was reasonable.

After determining the structure, mechanical and corrosion behavior of these materials, the following conclusions were attained.

1. Dense sintered pure magnesium and silica reinforced magnesium composites were synthesized using mechanical alloying and SPS technique.

2. The elastic modulus of sintered composites did not change significantly as compared to pure magnesium.

3. A slight increase in the microhardness of the composites implies that low weight percent silica reinforcement offers resistance to localized deformation.

4. The corrosion behavior measured using potentiodynamic polarization test in PBS solution at $37^{\circ} \mathrm{C}$ showed a significant improvement for silica reinforced composites.

Thus, these nanocomposites could be a viable candidate as a biomaterial for implants and fixation devices and need further evaluation with series of cell culture studies.

\section{Acknowledgements}

One of the authors Devadas Bhat Panemangalore thanks University of Lille for supporting his graduate program and providing facilities for carrying out the experiment. The authors also 
acknowledge Conseil Regional du Nord-Pas de Calais and the European Regional Development Fund (ERDF) for the support of the XRD, SEM national facility in Lille (France).

\section{References}

[1] J. Nagels, M. Stokdijk, P.M. Rozing, Stress shielding and bone resorption in shoulder arthroplasty, J. Shoulder Elb. Surg. 12 (2003) 35-39. doi:10.1067/mse.2003.22.

[2] M. Gupta, G.K. Meenashisundaram, Insight into Designing Biocompatible Magnesium Alloys and Composites, Springer Singapore, Singapore, 2015. doi:10.1007/978-981287-372-9.

[3] K.F. Farraro, K.E. Kim, S.L.-Y. Woo, J.R. Flowers, M.B. McCullough, Revolutionizing orthopaedic biomaterials: The potential of biodegradable and bioresorbable magnesium-based materials for functional tissue engineering, $\mathrm{J}$. Biomech. 47 (2014) 1979-1986. doi:10.1016/j.jbiomech.2013.12.003.

[4] X.-N. Gu, Y.-F. Zheng, A review on magnesium alloys as biodegradable materials, Front. Mater. Sci. China. 4 (2010) 111-115. doi:10.1007/s11706-010-0024-1.

[5] E. Zhang, L. Xu, G. Yu, F. Pan, K. Yang, In vivo evaluation of biodegradable magnesium alloy bone implant in the first 6 months implantation, J. Biomed. Mater. Res. Part A. 90 (2009) 882-893.

[6] G. Song, Recent progress in corrosion and protection of magnesium alloys, Adv. Eng. Mater. 7 (2005) 563-586.

[7] S. Zhang, X. Zhang, C. Zhao, J. Li, Y. Song, C. Xie, H. Tao, Y. Zhang, Y. He, Y. Jiang, Y. Bian, Research on an $\mathrm{Mg}-\mathrm{Zn}$ alloy as a degradable biomaterial, Acta Biomater. 6 (2010) 626-640. doi:10.1016/j.actbio.2009.06.028.

[8] X.N. Gu, N. Li, Y.F. Zheng, L. Ruan, In vitro degradation performance and biological response of a $\mathrm{Mg}-\mathrm{Zn}-\mathrm{Zr}$ alloy, Mater. Sci. Eng. B. 176 (2011) 1778-1784. doi:10.1016/j.mseb.2011.05.032.

[9] Y. Liao, Y. Ouyang, J. Niu, J. Zhang, Y. Wang, Z. Zhu, G. Yuan, Y. He, Y. Jiang, In vitro response of chondrocytes to a biodegradable $\mathrm{Mg}-\mathrm{Nd}-\mathrm{Zn}-\mathrm{Zr}$ alloy, 2012. doi:10.1016/j.matlet.2012.05.111.

[10] M.-H. Kang, T.-S. Jang, S.W. Kim, H.-S. Park, J. Song, H.-E. Kim, K.-H. Jung, H.-D. Jung, MgF2-coated porous magnesium/alumina scaffolds with improved strength, corrosion resistance, and biological performance for biomedical applications, Mater. Sci. Eng. C. 62 (2016) 634-642. doi:10.1016/J.MSEC.2016.01.085.

[11] H. Amiri, I. Mohammadi, A. Afshar, Electrophoretic deposition of nano-zirconia coating on AZ91D magnesium alloy for bio-corrosion control purposes, Surf. Coatings Technol. 311 (2017) 182-190. doi:10.1016/j.surfcoat.2016.12.103.

[12] P. Amaravathy, S. Sathyanarayanan, S. Sowndarya, N. Rajendran, Bioactive HA/TiO2 coating on magnesium alloy for biomedical applications, Ceram. Int. 40 (2014) 6617- 
6630. doi:10.1016/J.CERAMINT.2013.11.119.

[13] H.R. Bakhsheshi-Rad, E. Hamzah, M. Kasiri-Asgarani, S.N. Saud, F. Yaghoubidoust, E. Akbari, Structure, corrosion behavior, and antibacterial properties of nanosilica/graphene oxide coating on biodegradable magnesium alloy for biomedical applications, Vacuum. 131 (2016) 106-110. doi:10.1016/J.VACUUM.2016.05.021.

[14] P.C. Ferreira, K. de A. Piai, A.M.M. Takayanagui, S.I. Segura-Muñoz, Aluminum as a risk factor for Alzheimer's disease., Rev. Lat. Am. Enfermagem. 16 (n.d.) 151-7. http://www.ncbi.nlm.nih.gov/pubmed/18392545 (accessed June 14, 2018).

[15] G.R. Beck, S.W. Ha, C.E. Camalier, M. Yamaguchi, Y. Li, J.K. Lee, M.N. Weitzmann, Bioactive silica-based nanoparticles stimulate bone-forming osteoblasts, suppress bone-resorbing osteoclasts, and enhance bone mineral density in vivo, Nanomedicine Nanotechnology, Biol. Med. 8 (2012) 793-803. doi:10.1016/j.nano.2011.11.003.

[16] L. Yildirimer, N.T.K. Thanh, M. Loizidou, A.M. Seifalian, Toxicology and clinical potential of nanoparticles, Nano Today. 6 (2011) 585-607. doi:10.1016/J.NANTOD.2011.10.001.

[17] S. Wang, X. Wang, F.G. Draenert, O. Albert, H.C. Schröder, V. Mailänder, G. Mitov, W.E.G. Müller, Bioactive and biodegradable silica biomaterial for bone regeneration, Bone. 67 (2014) 292-304. doi:10.1016/j.bone.2014.07.025.

[18] M. Kong, J. Tang, Q. Qiao, T. Wu, Y. Qi, S. Tan, X. Gao, Z. Zhang, Biodegradable hollow mesoporous silica nanoparticles for regulating tumor microenvironment and enhancing antitumor efficiency, Theranostics. 7 (2017) 3276-3292. doi:10.7150/thno.19987.

[19] M. Kursawe, W. Glaubitt, A. Thierauf, Biodegradable Silica Fibers from Sols, J. SolGel Sci. Technol. (1998) 267-271.

[20] X. Wang, H.C. Schröder, M. Wiens, H. Ushijima, W.E.G. Müller, Bio-silica and biopolyphosphate: Applications in biomedicine (bone formation), Curr. Opin. Biotechnol. 23 (2012) 570-578. doi:10.1016/j.copbio.2012.01.018.

[21] F. Natalio, T. Link, W.E.G. Müller, H.C. Schröder, F.Z. Cui, X. Wang, M. Wiens, Bioengineering of the silica-polymerizing enzyme silicatein- $\alpha$ for a targeted application to hydroxyapatite, Acta Biomater. 6 (2010) 3720-3728. doi:10.1016/j.actbio.2010.03.010.

[22] G. Bhakta, R.K. Sharma, N. Gupta, S. Cool, V. Nurcombe, A. Maitra, Multifunctional silica nanoparticles with potentials of imaging and gene delivery, Nanomedicine Nanotechnology, Biol. Med. 7 (2011) 472-479. doi:10.1016/j.nano.2010.12.008.

[23] G. Parande, V. Manakari, G.K. Meenashisundaram, M. Gupta, Enhancing the hardness / compression / damping response of magnesium by reinforcing with biocompatible silica nanoparticulates, Int. J. Mater. Res. 107 (2016) 1-9.

[24] L. Lu, M.O. Lai, M.L. Hoe, Formation of nanocrystalline Mg2Si and Mg2Si dispersion strengthened $\mathrm{Mg}-\mathrm{Al}$ alloy by mechanical alloying, Nanostructured Mater. 10 (1998) $551-563$.

[25] L. Wang, X.Y.Y. Qin, W. Xiong, X.G.G. Zhu, Fabrication and mechanical properties 
of bulk nanocrystalline intermetallic Mg2Si, Mater. Sci. Eng. A. 459 (2007) 216-222. doi:10.1016/j.msea.2007.01.038.

[26] K. Kondoh, H. Oginuma, A. Kimura, S. Matsukawa, T. Aizawa, In-situ Synthesis of Mg2Si Intermetallics via Powder Metallurgy Process, Mater. Trans. 44 (2003) 981985.

[27] B. Sun, S. Li, H. Imai, J. Umeda, K. Kondoh, M. Si, Kinetic Analysis of Solid-State Formation of Mg2Si by Powder Metallurgy Process, (2011) 9-13.

[28] K. Kondoh, T. Luangvaranunt, New process to fabricate magnesium composites using $\mathrm{SiO} 2$ glass scraps, Mater. Trans. 44 (2003) 2468-2474.

[29] A. Olszówka-Myalska, S.A. McDonald, P.J. Withers, H. Myalska, G. Moskal, Microstructure of in-situ Mg Metal Matrix Composites Based on Silica Nanoparticles, Solid State $\quad$ Phenom. 191 (2012) 189-198. doi:10.4028/www.scientific.net/SSP.191.189.

[30] R.K. Gupta, N.L. Sukiman, K.M. Fleming, M.A. Gibson, N. Birbilis, Electrochemical Behavior and Localized Corrosion Associated with $\mathrm{Mg} 2 \mathrm{Si}$ Particles in $\mathrm{Al}$ and $\mathrm{Mg}$ Alloys, ECS Electrochem. Lett. 1 (2012) C1-C3. doi:10.1149/2.002201eel.

[31] G. Ben-Hamu, D. Eliezer, K.S. Shin, The role of Mg2Si on the corrosion behavior of wrought Mg-Zn-Mn alloy, Intermetallics. $16 \quad$ (2008) 860-867. doi:10.1016/j.intermet.2008.03.003.

[32] G. Ben-Hamu, D. Eliezer, K.S. Shin, The role of Si and Ca on new wrought Mg-ZnMn based alloy, Mater. Sci. Eng. A. 447 (2007) 35-43. doi:10.1016/j.msea.2006.10.059.

[33] N. Birbilis, R.G. Buchheit, Electrochemical Characteristics of Intermetallic Phases in Aluminum Alloys, J. Electrochem. Soc. 152 (2005) B140. doi:10.1149/1.1869984.

[34] S.N. (Suveen N. Mathaudhu, W.H. (Wim H. Sillekens, N.R. (Neal R. Neelameggham, N. Hort, M. and M.S.A.M. (141st: 2012: O. Minerals, M. and M.S.M.C. Minerals, Magnesium technology 2012: proceedings of symsposium sponsored by the Magnesium Committee of the Light Metals Division of The Minerals, Metals \&amp; Materials Society (TMS); held during TMS 2012 Annual Meeting \&amp; Exhibition, Orlando, Flordia, USA, $\quad$ Ma, https://books.google.fr/books?id=iNPBDQAAQBAJ\&pg=PA221\&lpg=PA221\&dq=hi gh+melting + point $+\mathrm{Mg} 2$ Si\&source=bl\&ots=i7HWqhbdCy\&sig=GkNQpIl6yBPUxsYv69XALCS4Bg\&hl=en\&sa=X\&ved=0ahUKEwj5sdfRkcPYAhXEwBQKHWIlCrgQ6

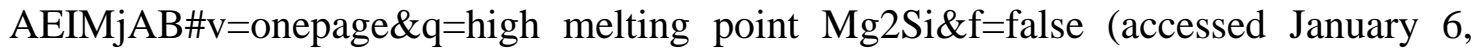
2018).

[35] X. Niu, L. Lu, Formation of magnesium silicide by mechanical alloying, Adv. Perform. Mater. 4 (1997) 275-283. doi:10.1023/A:1008673004625.

[36] M.D. Michel, F.C. Serbena, C.M. Lepienski, Effect of temperature on hardness and indentation cracking of fused silica, J. Non. Cryst. Solids. 352 (2006) 3550-3555. doi:10.1016/J.JNONCRYSOL.2006.02.113.

[37] Phosphate buffered saline tablet | Sigma-Aldrich, (n.d.). https://www.sigmaaldrich.com/catalog/product/sigma/79382?lang=fr\&region=FR 
(accessed May 2, 2018).

[38] L. Wang, X.Y. Qin, The effect of mechanical milling on the formation of nanocrystalline Mg2Si through solid-state reaction, Scr. Mater. 49 (2003) 243-248. doi:10.1016/S1359-6462(03)00241-0.

[39] F. Andreatta, I. Apachitei, A.A. Kodentsov, J. Dzwonczyk, J. Duszczyk, Volta potential of second phase particles in extruded AZ80 magnesium alloy, Electrochim. Acta. 51 (2006) 3551-3557. doi:10.1016/j.electacta.2005.10.010.

[40] M. Aydin, C. Özgür, O. San, Microstructure and hardness of Mg-based composites reinforced with Mg2Si particles, Rare Met. 28 (2009) 396-400. doi:10.1007/s12598009-0070-y. 